\title{
Conference on the Teaching of General Science
}

\begin{abstract}
A SUB-COMMITTEE of the Science Masters' Association, acting in collaboration with the University of London Institute of Education, recently organised a one-day conference on the teaching of 'general science'. The problems discussed have caused much controversy during the past few years. The panel of investigators on the School Certificate examinations recommended the adoption in schools of courses covering the main principles of elementary physics, chemistry and biology instead of more specialised courses covering only one, or part of one, of these subjects. At the annual meeting of the Science Masters' Association in 1934 this recommendation was endorsed. The movement is supported by those who consider that some study of biology should be part of the education of every child, as well as by those who wish school science to be less formal and less academic than it often is. It is opposed by those who fear superficiality of treatment and who feel that they can train children's minds more satis. factorily by using a more restricted medium. The large attendance at the conference, and the keen discussions which ensued, illustrated the general desire to thrash out the issues involved and to pool experience and knowledge.
\end{abstract}

Sir William Bragg took the chair at the first of the five meetings and initiated a discussion on "The Aims of General Science". The educated man, he said, should be aware of the main lines of development of human thought and, to-day, this involves an appreciation of the scientific attitude. It is important, too, that an intellectual atmosphere be fostered which is unfavourable to a misapplication of the fruits of research, due to lack of knowledge. Dr. Titley (King's College) amplified these remarks, and considered in detail aims which have been widely accepted. In particular, he gave a careful résumé of present views regarding the mind-sharpening value of scientific studies. $\mathrm{He}$ pointed out that exercising the mind within a narrow and specialised range might give it great power, but only in a very restricted field. The keen discussion which followed these stimulating addresses revealed fair unanimity of views. Clearly, it was found difficult to distinguish between the general aims of science teaching and the aims of general science, but this is an argument in favour of the latter. The teaching of 'Heat, Light and Sound', for example, would certainly not allow the attainment of the aims admitted.

Prof. E. N. da C. Andrade took the chair at the second meeting, the subject being "The Content of the Course". He admitted that wider syllabuses might lead to some superficiality of treatment, but could see no particular harm in this. Even the building up of 'balanced' courses, he thought, was really unessential. A scientific attitude and a love of science could best be fostered by a teacher who cast his net wide, but was not afraid to follow up his own pet hobbies. Prof. H. E. Armstrong should have followed Prof. Andrade but was unfortunately compelled to be absent for health reasons. He sent, how. ever, a stimulating and provocative message. Mr. C. L. Bryant (Harrow) then gave details of the minimum syllabus in general science which has been drawn up by the special sub-committee of the Science Masters' Association. The proposals were well received, though it was felt that a more optimistic attitude regarding time-table allowance would have been desirable. Many of the best schools give twice as much time to science as is contemplated by the sub-committee.

At the first afternoon meeting, held under the chairmanship of Mr. H. T. Tizard, problems of unification and correlation were considered. $\mathrm{Mr}$. W. G. Greaves (Ledbury Grammar School) criticised the use of the topic method of teaching, in which topics such as air, water, measuring instruments, etc., are studied and no attempt is made to keep the subjects separated. He considered this to be useless as a method of unification, admirable though it might be as a teaching device.

Mr. J. A. Lauwerys (Institute of Education) discussed the point as to whether there was sufficient unity in the various branches of school science to make it a single subject. He put more faith in the integrating powers of the intellectual digestion of the adolescent mind than in those of various sylla. buses or methods. Topics would certainly be useful in the first two years of study, but there was no reason to avoid 'subjects' at a later stage when logical interconnexions could be demonstrated and understood. The hints and comments made by speakers who took part in the subsequent discussion will probably be useful to those who are attempting to make their subject more interesting and valuable to the average pupil.

Sir Philip Hartog then took the chair for a dis. cussion on examinations. He had been struck during the discussions, he said, by the importance attached to examination requirements. It appeared that examinations held the educational system in a stranglehold. He suggested that teachers should be clear as to the aims of their tests : they should know, for example, whether they were testing progress or utilisable skills. $\mathrm{He}$ recommended them to study the new-type questions, which the Americans have done much to develop.

The subsequent discussion, initiated by Mr. S. V. Brown (hon. secretary of the S.M.A.) and Mr. F. W. Turner (Morley Grammar School), showed that most teachers deplore the restrictive influence of examins. tions on their work. Though ready to admit that external examinations are not valueless, they would like to see fundamental alterations and improvements.

The three addresses to the last meeting - on "The Teacher of General Science"-admirably summarised the previous arguments. The chairman, Prof. H. R. Hamley (Institute of Education), Mr. W. H. Jenkinson (Sheffield) and Mr. L. G. Smith (Marylebone Grammar School) developed various aspects of this topic. The discussion which followed revealed unanimous agree. ment with their views. To make school science a valuable and useful part of a liberal education the right teachers must be provided by the universities. They must be enthusiasts who should know not only their own subject but also the role which it plays in the greater whole of which it is a part. Clearly 
a. wide and generous training in science would do more to provide such people than the narrow and intensively specialised courses favoured by some universities.

It is possible that the conference did not reach conclusions as explicit and as concrete as some might have wished. Nevertheless, the addresses and discussions were highly appreciated and were found stimulating and helpful. Wide agreement with the ideals of more generalised science teaching was shown, though it was evident that quite a number of teachers are not yet convinced of its benefits.

\section{Food and the Family Budget}

$\mathrm{T}$ HAT the social and economic aspects of national nutrition are evoking great public interest was shown by the crowded audience at the joint meeting of the Engineers' Study Group on Economics (E.S.G.) and the Association of Scientific Workers, held on March 31 at the house of the Royal Society of Arts, London. In a short introductory speech, Sir Richard Gregory urged the importance of investigating the causes why commodities that can now be produced in abundance, thanks to science, are not available in sufficient quantities to raise the standard of living of the people. He then called upon Dr. E. H. Tripp to present and explain the Group's report on "The Design of a Family Budget, with special reference to Food".*

The main finding of the report is that the statistical average family of 3.72 persons requires annually, for adequate living, goods and services now costing about $£ 317$, a sum equivalent to a weekly expenditure of about 63s. per wage-earner. About 82 per cent of 'families' are now earning less than this amount.

The chief items in the prescribed 'family' budget are (per annum) : food, £99; rent and rates, £55, the type of house envisaged being one containing a living-room, three bedrooms, kitchen and bathroom, costing $£ 600-£ 800$ inclusive of land; clothing, $£ 28$; fuel and light, divided between gas, electricity and but little raw coal, $£ 21$; smoking, liquor, and sweet-

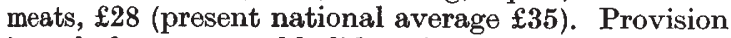
is made for an annual holiday, $£ 10$, and for travelling, $£ 20$ (present national average £22).

of especial importance in the prescribed dietary are the health foods, fresh dairy produce, eggs, meat, vegetables and fruit. The cost works out to $10 \mathrm{~s}$. a head per week, as compared with $9 s$, the current national average; and the conclusion is that a large section of the population has not the purchasing power needed to obtain the foods required for full health and working capacity.

In opening the discussion, Sir John Orr welcomed the fact that scientific workers have now begun to apply their knowledge and methods to social and economic problems, which cannot well be studied in water-tight compartments. The report of the E.S.G., he said, embodies an excellent study, and it is very remarkable that by approaching the subject from a totally different point of view and by different methods, the Group has reached a conclusion very close to that at which he and his colleagues arrived. Food requires a special place for itself. Whereas expenditure on items like entertainment, sport, and reading may vary from nothing to $£ 1,000$ a year, that on food varies much less from class to classnot more than from $4 s$. to 14s. a head per week between the poorest and the wealthiest. Appetite is limited, and although one might pay $£ 1$ for a dinner in London, one could not eat more than 10s. worth of food, at retail prices. Also, the State has assumed a special liability for food by undertaking to treat and cure diseases due to an inadequate diet. Very few people starve nowadays, but many lack a diet sufficient to maintain good health. To provide an adequate diet for all people below the income-level of $£ 317$ per annum would involve, at retail prices, an increase in the national expenditure of about 5-6 per cent ; but a cheaper method, and one more likely to be adopted, would be to cheapen the protective foodstuffs so that all could buy them; and that would reduce the increased expenditure to 1-2 per cent. More study and more criticism are needed to evoke concrete propositions; and once the bulk of the people is convinced, great improvement would follow.

Sir Daniel Hall said that if we increased the amount of home-grown food from the present figure of less than 40 por cent to more than 50 per cent of our total supplies, agricultural conditions would have to be revolutionised. We should certainly grow all the protective foodstuffs we can, and our land is specially suited to grow them. He disapproved the policy of subsidising wheat and sugar because they are needed in war-time; they are concentrated foods that are obtainable from our colonies, and occupy relatively little space in a ship's hold. As our farmers are now being assisted to the extent of more than $£ 40,000,000$ per annum, they could reasonably be expected to grow what is best for the country.

Mr. G. D. H. Cole agreed with the main points of the report, but regretted that the cost of education was not discussed. The food budget was certainly no more than is desirable, and it would probably be necessary to provide a larger total income. Urgently needed now are more data on expenditure at the $£ 6-£ 10$ a week income-level, and a new complete inquiry into working-class budgets.

Mr. A. E. Feavearyear commented on the cost of the improved housing prescribed in the E.S.G. budget. There are now some $10 \frac{1}{2}$ million houses in the United Kingdom, worth $£ 4,000-£ 5,000$ million at present prices. Assuming a house to last a hundred years, the annual cost of replacement would not amount to $£ 50,000,000$. He advocated a fairly rapid replacement of all houses below the E.S.G. standard -not less than 3 millions-but that would cost at least $£ 1,500,000,000$, or more than the entire net annual savings of the nation for five years.

Lady (Rhys) Williams described a study of infant and maternal mortality as affected by nutrition, carried out in the Rhondda Valley under the National Birth. day Trust Fund. Necessitous mothers were given vitamin-bearing foods and 1 pint of milk a day for at least three months, with the result that the maternal death-rate fell from 11.29 in 1934 to 3.9 in 1935 . 